\title{
DIE INKLEDING VAN DIE BOODSKAP VAN DIE HEILIGE SKRIF
}

\section{DR. MURRAY JANSON}

Die skrifbeskouing is in die kring van die Gereformeerde kerke op die oomblik een van die mees besproke en omstrede temas van die teologie'). Die sogenaamde "Cahiers voor de Gemeente" wat tot dusver verskyn het, hou almal hiermee verband. Die besware van die sogenaamde verontrustes trek hulself feitlik almal op hierdie een punt saam. Daar moet in hierdie verband ook gewys word op Berkouwer se twee standaardwerke op hierdie terrein: De Heilige Schrift I en II. Ook H. M. Kuitert se omstrede: „Verstaat gij wat gij leest?" wat alreeds 'n hele ry ander werke as teen-reaksies ontlok het ${ }^{2}$ ). Ook dien gewys te word op die besluit van die Generale Synode van die Gereformeerde Kerken, gehow te Amsterdam/Lunteren in 1967, dat die uitspraak van die sinode van Assen (1926) betreffende die saak - dr. J. G. Geelkerken ,niet langer als leeruitspraak in de kerken zal gelden", en ook weer die wye reaksie hierop ${ }^{3}$ ).

Maar dit geld ook die Nederlandse Hervormde Kerk. Reeds in 1953 het die Generale Synode 'n geskrif „Leer aangaande de Heilige Schrift" van hom laat uitgaan. En in 1966 is die redelik lywige werk "Klare Wijn"4) met algemene stemme deur die sinode aanvaar as hulp by die lees van die Bybel, en om gemeentelede in verband met onsekerhede in hierdie verband in te lig en rigting te gee. Hierdie boek het drie maande na sy verskyning reeds drieërlei druk beleef.

Draai ons die soeklig na Duitsland, dan vind ons dat daar in verband met die gesag van die Skrif en aanverwante vraagstukke, gedurende die afgelope dekade 'n onophoudelike stroom van werke en artikels verskyn het - 'n stroom wat homself nou nog nie uitgewoed het nie. Uit bekommernis oor die rigting wat vele teoloë in dié verband inslaan, het daar op 6 Maart 1966 'n groot byeenkoms van 22,000 Protestante in Dortmund plaasgevind, onder die leuse: die Here het waarlik opgestaan. Daarna het dié wat opgedaag het hulle verenig in 'n soort belydenis beweging, met die naam: „Geen ander evangelie," onder leiding van pastor Bäumer en pastor Deitenbeck ${ }^{5}$ ).

1. C. Augustijn. Kuypers rede over .de hedendaagsche Schriftcritiek in haar historische context'. G.T.T.. Febr. 1969. D. 18.

2. O.a.: G. Visee: Verstaat prof. Kuitert wat hij leest?

?.a. J. Schelhaas. De val van Assen, Vlaardingen 1968 . Vergelyk ook: B. W. Ganzevoort. De Bijbel in het Geding. Kampen 1968.

4. Subtitel: Rekenschap over geschiedenis, geheim en gezag van de Bijbel, 's Gravenhage 1967.

5. Sien Werner Harenberg: Jezus en de Kerken, Bijbelcritiek en confessie, p. 13. 
Nou het dit alles ook nie onopgemerk by die deur van die Rooms-Katolieke kerk verbygegaan nie. Die Roomse teologie van ons tyd word gekenmerk deur 'n voortgaande en steeds meer intensiewe Bybelstudie - 'n studie wat hom nie onbetuig kon laat nie en op baie gebiede gisting en vrae laat ontstaan het ${ }^{6}$ ). 'n Mens dink ook hier aan die ontstaan van „De Nieuwe Katechismus" onder leiding van die biskoppe van Nederland ${ }^{7}$ ).

Uit hierdie wetenskaplike omgang met die Skrif kom meteen die vraag op: hoe raak die Skrif ons vandag? Wat is die boodskap van die Bybel? Hoe moet ons daarteenoor staan? En hierdie "ons" is dan natuurlik veral die sogenaamde "mondige mens", die moderne mens wat sy nood uitgedruk het by monde van Viktor von Weiszäcker. Hy verklaar dat die moderne mens vandag saam met sy hoed en sy stok, soggens ook sy God aan die spyker van die laboratorium ophang. Want hier in die laboratorium vind hy onteenseglik sekere bewysbare waarhede wat (skynbaar) met die Bybel, of met die Bybel soos die kerk hom interpreteer, in stryd is. Maar hy is as wetenskaplike maar te bewus daarvan dat hy sonder God nie kan of wil lewe nie daarom neem hy sy God saans saam met sy hoed en sy baadjie weer van die spyker af in die lewe met hom saam ${ }^{8}$ ).

Met ander woorde, die vraag ontstaan of die Skrif altyd letterlik geïnterpreteer wil word, en of sekere gedeeltes dalk op 'n ander wyse verklaar moet word. Of nog anders gevra: is daardie gedeeltes dalk nie deel van die boodskap van die Bybel nie? Behoort dit tot die inkleding, of die verpakking - die tydgebonde, onbelangrike, irrelevante omhulsel waarin die eintlike boodskap van die Bybel geklee is?

\section{Die gevare wat aan die begrip ,inkleding" of „verpakking” kleef.}

Die vraag ontstaan dadelik of ons nie met so 'n siening weer terug is by ' $n$ dualistiese beskouing oor die heilige Skrif nie? As die eenheid van die Bybel opgeoffer word en dit uiteengerafel word in goddelike en menslike gedeeltes, as die vorm van die inhoud losgemaak en alleen die inhoud belangrik geag word, of

6. Mens dink in dié verband aan die probleme wat die sg. Formgeschichtliche metode vir Rome gebring het. Heinrich Schlier 'n dissipel van hierdie metode wat tot die R.K. oorgegaan het plaas nou daar saam met ander allerlei vraagtekens oor sake wat eeue lank ontwy fel. haar aanvaar is. Bv. die vraag of Matt. 16 - die Skriftuurplaas vir die fundering van die primaat en onfeilbaarheid van die pous - nie miskien 'n skepping van die oergemeente is nie, 'n aposterioriese interpretasie! Vgl. Berkouwer, Vatikaans Concilie en Nieuwe Theologie, p. 155 -

i. Sien bv.: De Nieuwe Katechismus, Geloofsverkondiging voor volwassenen. Roermond-Maaseik. 1966.

8. Aangehaal by Zahrnt, Die Sache mit Gott, p. 165. 
die sogenaamde religieuse of religieus-etiese boodskap as die eintlike Woord uitgelig word? Draai ons dan nie die horlosie terug na die tragiese tyd van die 19de eeu se teologie nie? En open ons nie daarmee saam weer die hek vir die skadelike allegorese nie? Hartvelt het juis op interessante wyse aangetoon hoedat die allegorese op profane, naamlik in die Griekse filosofie ontstaan het, en wel toe die oorgelewerde verhale oor die gode moeilik met eerbaarheid en fatsoenlikheid gerym kon word. Om dit te ondervang, het die filosowe met die voorstel gekom dat daar aan die woorde van die digters 'n verborge sin ten grondslag lê. En die allegorie het dan probeer om hierdie verborge sin op die spoor te $\mathrm{kom}^{9}$ ). Dit sou verskriklik wees as die eksegese die kerk en die teologie vandag weer terugdring na die allegoriese Bybelverklaring!

'n Verdere vraag ('n nog dringender gevaar): Word die Skrif nie langs hierdie weg ,verharmlos”, onskadelik gemaak nie? As die mens telkens kan uitmaak wat verpakking en wat boodskap in die Skrif is, heers die mens dan nie lankal reeds oor die teks nie? Word die teks dan nie aan 'n van buite af opgelegde skema onderwerp nie. Word die evangelie wat eers deur die filter van ons skemas moet gaan, nie tot 'n absolute minimum of tot 'n niks gereduseer nie? En is die slot van dit alles nie dat ons uitkom by die prediking van Lange en Marxsen en ander waar die hele Nuwe Testament eenvoudig as mitologiese verpakking gesien word nie? Volgens hulle bied die Nuwe Testament nie preektekste nie, maar alleen maar voorbeelde van die prediking in die vroegste christelike kerk oor 'n "teks" wat ons nie het nie en ook nooit sal vind nie. Die Nuwe Testament kan ons help om daardie teks te probèèr vind, soos Erasmus byboorbeeld die Latyn in die Grieks terugvertaal het! $\left.{ }^{10}\right)$.

Maar nou móét ons ook op die ander kant van die saak wys, naamlik dat dit nie meer so maklik is om te beweer: ek staan alleen maar op dit wat die Skrif sê nie - omdat daar ook in hierdie verband probleme opgeduik het wat nie weggeredeneer kan word nie. Dit baat hier nie om uit vrees vir die liberale rigtings op hierdie gebied, weer per slot van rekening in die ewe groot gevaar van die Dosetisme in verband met die Skrif te verval nie. Met ander woorde dat ons in ons nadenke oor die Heilige Skrif dit nie in rekening bring dat die Woord van God deur mensediens en in menslike woorde tot ons gekom het nie. Hier dreig die monster van die biblisisme en van sy Amerikaanse tweelingbroer die fundamentalisme - 'n skrifgebruik wat die

๑. Hartvelt, Goed yoor Gods Woord, Cahier no. 3, p. 22.

10. Vgl. E. Lange, P. Krusche en D. Rössler: Predigtstudien, Kreuz-Verlag mit Beiheft. 
Bybelteks reëlreg oorbring na ons tyd en situasie, sonder om rekening te hou met die verkondigingskarakter van die teks en met die situasie van die skrywers en die boeke. Die formule "dit staan tog in die Bybel" word as einde van alle teenspraak hanteer, maar sonder om te vra "hoe" en „waar" en „waarom” dit daar staan; en uiteindelik slaan hierdie christelike grondwaarheid om in sy teendeel en staan dit die regte verstaan van die Bybel in die weg ${ }^{11}$ ).

Die beste voorbeeld hiervan is vandag die Skriftoepassing en uitleg van die Jehova-getuies. Alles word eenvoudig gelyk geskakel in die Bybel. Die lys van die nakomelinge van Sem word net so belangrik geag as die Johannes-Evangelie. Bybeltekste word hanteer soos 'n kind dit met blokkies doen: willekeurig word almal asof van gelyke waarde, opmekaar gestapel om die vereiste toring te verkry. Die Bybel word tot ' $n$ orakelboek $^{12}$ ) en 'n koran van die christenheid ${ }^{13}$ ) verlaag.

Dit het vandag duidelik geblyk dat die eenvoudige uitspraak: ek glo maar net wat daar letterlik in die Skrif staan, nie so eenvoudig is as wat dit klink nie. Gedurende die vorige eeu was dit byvoorbeeld juis hierdie Skrifbeskouing wat die gehoorsaamheid aan die Skrif in die weg gestaan het! Die afskaffing van slawerny - die absolute konsekwensie van die evangelie! - is met Bybeltekste teengestaan $\left.{ }^{14}\right)$.

\section{DIE WESE VAN DIE SAAK:}

Miskien is ons dadelik by die wese van die saak as daarop gewys word dat ons almal gedurig sélf 'n sekere onderskeiding tussen Skrifgedeeltes of -verse maak, selfs ten opsigte van Skrifgebooie; dat sekere dinge vir ons lank nie dieselfde waarde en gesag as ander het nie. Die Generale Synode van die Gereformeerde Kerken (1965) het gepraat van allerlei konkreet gegewe gebooie, wat "mede deur die toenmaalige sedes bepaal is" en voorts van die "tydgebondenheid" van sekere voorskrifte; op grond daarvan is hierdie sedes , as sodanig vir ons nie meer normatief te ag nie"15). In dié verband verklaar Bavinck dat „veel

1i. Bijlsma het dit baie goed getipeer in sy Schriftgezag en Schriftgebruik, p. 84. Vgl. ook Berkouwer, De Heilige Schrift I. p. 21-; en II, p. 114-. Ook Bremmer De Heilige Schrift als Woord Gods, In die Skriflig, Okt. '66. p. 26-; en Klare Wijn. pp. 70. 177.

12. Kurt Hutten, Seher, Grübler. Enthusiasten, p. 123.

13. Kuyper: ,Er kwam iets bibliolatrish, iets fetischachtigs in het vergoden van die papieren bladen waarvan men .als het stofgoud van den vlinder. den lichtenden dauwdrop des geestes had weggeblazen" - by Augustijn, a.w., p. 20.

14. Vgl. da Costa se tirade by H. Jonker. Actuele Prediking, p. 59. Die teëstanders van Tarma het hom weer Kol. 3: 22 voorgewerp as bewys dat slawerny deur God gewil sou wees - Klare Wijn, p. 70 .

15. Aangehaal by Berkouwer II, p. 104. 
van die deur God gebodene en gestelde ons nie regstreeks meer aangaan nie" en allermins vir ons normatief is. Die Skrif kan en mag nie as 'n wetboek vol artikels opgevat word nie. Die gesag van die Skrif is ' $n$ ander as die van 'n staatswet ${ }^{16}$ ).

So word die praktyk van die groet "met die heilige kus", hoewel Paulus dit vier maal en Petrus dit een maal beveel, glad nie meer in die erediens gebruik nie. Niemand sou vandag beswaar hê om bloedwors te eet nie, en dit ondanks die pertinente verbod in Handelinge 15:29. Al maak Paulus 'n baie sterk saak uit teen ,elke vrou wat bid of profeteer met onbedekte hoof" (1 Kor. 11:5), besoek die Europese vrou reeds lank die kerk sonder hoofbedekking.

Maar die saak word nog veel ernstiger as 'n mens kom by die sogenaamde wêreldbeeld(e) van die Heilige Skrif. So lees ons in Josua 10:12 en 13 dat die son op die dag van Josua se groot triomf in Gibeon, stilgestaan het. Op grond van hierdie tekste is die natuurkundige Galilio Galilei deur die Roomse inkwisisie gedwing om die insigte van Copernicus af te sweer. Copernicus en Galilei se boeke het tot 1935 op die lys van verbode boeke gestaan. Ook onder Protestante was hierdie teks die laaste woord en het iemand soos Luther byvoorbeeld, die insigte van Galilei eenvoudig as onbybels en onwaar verwerp. Hoogleraars en predikante wat Galilei se voorstellings toegestem het, is nog tot die einde van die 17de eeu in Holland aangekla en afgesit ${ }^{17}$ ).

Hieruit blyk duidelik dat die ongenuanseerde beroep op die Skrif onreg aan die Skrif self doen. Maar nou bly die vraag nog hoe Josua 10:12 en ander aanverwante gedeeltes verklaar moet word. Oorbekend is Bultman se reaksie met sy "erledigt". Volgens hom is die wêreldbeeld van die Nuwe Testament as dié van 'n soort drie-verdiepinggebou uitgedien. Maar dan ook daarmee saam alles wat daarmee in verband staan: die hemelen hellevaart van Christus; die verwagting van die op-die-wolkekomende Menseseun en die wegraping van die gelowiges die lug in; die geloof aan geeste en demone. ,'n Mens kan nie elektriese lig en radio-apparaat benut, in gevalle van krankheid, moderne medisyne en kliniese middele gebruik en tegelykertyd aan die geestes- en wonderwêreld van die Nuwe Testament glo nie. Daarmee sou die eintlike aanstoot van die evangelie bedek word en in plaas daarvan van die mens die vrome goeie werk van 'n sacrificium intellectus verlang word"18). Daarteenoor het die

\footnotetext{
16. G.D., I, p. 429.

1i. Kuitert, Verstaat gij wat gii leest? p. 26, vgl. Hartvelt a.w., p. 15-

19. Kyrugma und Mythos, 1960, pp. 18-19. Aangehaal by Otto Weber, Grundlagen I, p. 377.
} 
heilshistoriese interpretasie in ons tyd groot opgang gemaak ${ }^{10}$ ). Die heilshistoriese interpretasie veronderstel dat die uitlegger positief staan teenoor die denk- en leefwerreld van die verskillende fases in die heilsgeskiedenis. Die openbaring is immers nie 'n tydlose waarheid nie en daarom is dit wat tydgebonde is geen negativum nie, maar 'n positivum. Dit funksioneer mee, hoewel dit nie meer adekwaat is nie. T. C. Frederikse tipeer hierdie interpretasie as: „Hier word 'n vrye deurgangsweg geopen tussen enersyds 'n fundamentalistiese „vir waar hou" en andersyds 'n kritiese „redusering" ${ }^{20}$ ).

Maar ons kom by die crux van die saak as gevra word of alles wat in die Bybel staan op feitlikheid staat maak; met ander woorde moet en wil alles as geskiedenis gelees word, of is sommige gedeeltes alleen maar deel van die inkleding van die boodskap van die Skrif? Dit is besonder ernstige dinge hierdie waarby ons nie maar goedskiks kan verbyblaai nie. Dit is onvermydelik dat ons die saak met die noem van voorbeelde sal belig en sodoende die eintlike probleem aan die lig stel.

Dit is so dat daar in die Bybel gespreek word oor mitiese figure: die Leviatan, die Behemot en Rahab en dat daarin aanrakingspunte met sondvloedverhale van naburige volke voorkom, wat veel ouer as Genesis 6-8 is.

Voorts word vandag daarop gewys dat die vroegste geskiedenisse wat in die Bybel ter sprake kom, aanvanklik vir etlike honderde jare oorvertel is, voordat dit neergeskryf is. So ' $n$ mondelinge tradisie kan wel tot op 'n groot hoogte op betroubaarheid staatmaak, maar tog sou daar aan die menslike geheue onredelike eise gestel word, as daar verwag word dat bepaalde gebeurtenisse gedurende soveel duisende jare ongewysig deur vertel sou word. Koole ag dit net nie logies nie ${ }^{21}$ ). Vandaar dan ook - so verder Koole - dat daar vele onversoenbaarhede veral in die Ou Testament aangetref word. Koole wys byvoorbeeld daarop dat as die leeftyd van die persone van Genesis 11 noukeurig nagegaan word, dit skyn asof Sem en Abraham byna tydgenote was $^{22}$ ). Genesis 2:2-4 praat van 'n tuin in 'n wêreld wat een groot woestyn is, en tog verklaar Genesis 4:2 dat die uit die paradys verdrewe mensheid hom op veeteelt en landbou toegelê het. Kain is in Genesis 4:17 die stigter van 'n stad, maar volgens 4:20 is dit eers Jabal wat in 'n tent begin woon

1!. Verteenwoordig deur Noth, von Rad, Cullmann, Moltmann, Pannenberg, Berkhof. Sien van laasgenoemde: Revolte in de theologic, p. 90-.

${ }^{2 n}$. Th. C. Frederikse, Kerugma en Wereldbeeld, Ministerium, Nov. 1969, p. 164.

21. Cahier I. Verhaal en feit in het O.T., pp. 49-50.

2: A.w., p. 50. 
het. Dit is moeilik voorstelbaar hoe alle soorte diere 'n plek kon vind in 'n ark van slegs 300 el in lengte. Dit word enersyds as 'n groot wonder geskets dat Sara op so 'n hoë leeftyd nog moeder kon word, maar aan die ander kant word tog nie verklaar hoedat sy dan so aantreklik vir Farao en Abimeleg kon wees nie. Verder val dit op dat Abraham volgens Genesis 11:32, by die dood van Tera reeds 135 jaar oud was (vgl. Gen. 11:26), maar in Genesis 12:4 lees ons dat hy 75 jaar oud was by sy vertrek uit Haran.

In Josua 8:3 word verklaar dat Josua 'n hinderlaag van 30,000 man gebruik het by die inname van $\mathrm{Ai}$, terwyl die $12 \mathrm{e}$ vers weer sê dat dit alleen 5,000 man was ${ }^{23}$ ).

Die getalopgawes van die Ou Testament bied soms werklike probleme. Talle kere word die lengte van een of ander tydperk byvoorbeeld 40 jaar of 40 dae aangedui - só dikwels dat geleerdes soms wonder of hierdie getal nie 'n simboliese waarde het nie. In elk geval is daar 'n groot probleem met die 480 jaar wat volgens 2 Kon. 6:1 tussen die uittog en Salomo se tempelbou verloop het. Wanneer ons hierdie tempelbou in die middel van die lode eeu stel, moet die uittog in die $15 \mathrm{de}$ eeu plaasgevind het. Maar dit stry weer radikaal met alle gegewens van die oudheidskunde. Daarom stel Koole voor dat hierdie 480 jaar 'n aanduiding van 12 generasies was, waarby een generasie op 40 jaar gestel word. Dan word daar soms vrae gestel oor die besonder hoë getalle wat in die Bybel gedy. Rigters 20 vertel van die burgeroorlog tussen Benjamin en die Israelitiese stamme en nie minder nie as 400,000 man kom onder die wapen, waarvan 22,000 sneuwel en daarna nog 18,000 , dus in totaal 40,000 ! Volgens Koole is dit 'n vraag of so 'n geweldige groot leër op die been gebring kon word, en veral is moeilik te begryp waarom Saul se leër teen die Filistyne dan alleen maar 3,000 man getel het (1 Sam. 13:2). „Die noem van fabelagtig hoë getalle soldate skyn egter gewoonte te wees in die hele oud-oosterse oorlogsliteratuur"24).

Vele Ou Testamentici het hulle reeds afgevra hoe die groot getalle wat in Numeri by die uittog en die woestynreis genoem word, opgeneem moet word. Num. 1:46 spreek van 603,550 strydbare manne. As die vroue en kinders en die oues van dae daarby gereken word, dan kom dit op digby 2 miljoen te staan. Maar dit stel 'n mens voor vele vrae: wat beteken die twee vroedvroue van Exodus 1:15 op hierdie groot getal? Was die marskolonne nie te lank gewees om in én nag deur die Skelfsee te kon trek nie? Kon die land Gosen hierdie geweldige groot volk

23. Alle voorbeelde ontleen aan Koole.

24. Koole, a.w., p. 56. 
dra en herberg? Hoe kon so 'n byna ontelbare skare hom in die woestyn aan die lewe hou? In hierdie verband maak Koole die interessante stelling, dat juis hierdie laaste vraag synsinsiens nie gestel mag word nie, omdat dit aan die wondermag van God, wat sy volk deur die manna aan die lewe gehou het, afbreuk doen. Maar, so sê Koole, dit gaan hier om probleme waarvoor die Bybel self ons plaas. „Nie ons Skrifkritiek nie, maar inteendeel ons luister na die Skrif laat ons vra of hierdie groot getalle wel letterlik opgevat kan word" ${ }^{25}$ ); of anders gestel: of hierdie getalle tot inkleding behoort van die eintlike boodskap wat hulle aan ons wil bring?

Voorts staan ons voor feite waarvoor die opgrawings ons stel. Enersyds kan dit nie ontken word nie dat vele gegewens van die Ou Testament deur die argeologie bevestig is. Soms kan werklik gesê word dat die argeologie 'n illustrasieboek by Israel se geskiedenis is. Maar nou bly dit ook waar dat daar 'n sekere problematiek aan hierdie dinge verbonde is. Die verowering van Jerigo en Ai plaas ons voor nie-geringe probleme nie. Indien die Bybelse Ai tereg geïdentifiseer kan word met die huidige et-Tell, kan dit moeilik deur Josua verower gewees het, omdat hierdie plek blykens die opgrawinge, toe reeds 'n ruine was. Dit blyk uit die opgrawinges by Jerigo dat hierdie stad op dramatiese wyse ten onder gegaan het - maar dan meer as 500 jaar vór die intog! $\left.{ }^{26}\right)$. In dié verband dien ook gewys te word op boeke soos dié van $\mathrm{Gamm}^{27}$ ) en $\mathrm{Keller}^{28}$ ) waarin pogings gedaan word om te bewys dat die Bybel tog reg het. Dit is ongetwyfeld grootse pogings maar dit is ook waar dat die dinge wat daarin dikwels op simplistiese wyse gestel word, nie altyd so eenvoudig is as wat dit aangedien word nie. Harenberg toon aan dat Keller nie altyd wetenskaplik in sy bewerings is nie $^{2 \theta}$ ).

Dan moet ook die wonderverhale van die Ou Testament ter sprake kom. Hierdie wonders het uiteraard die ergenis van die geskiedeniswetenskap opgewek, wat onder invloed van die natuurwetenskaplike denke elke afwyking van die bekende natuurwette onmoontlik ag. Die natuur vorm tog 'n geslote samehang waarin alles sy oorsaak het; daarom gebeur daar geen wonders nie en het daar ook geen wonders gebeur nie - so word beweer. In reaksie hierop is daar dikwels probeer om aan te toon dat die Bybelse wonders nie onmoontlik was nie, omdat

\footnotetext{
25. A.w., p. 57.

20. Vgl. G. E. Wrigfit, An introduction to Biblical Theology, 1960, p. 47-; Hartvelt, a.w., p. 32, ook Koole, a.w. p. 59-.

27. Sachkunde zur biblischen Geschichte, München 1965.

29. Und die Bibel hat doch recht, Düsseldorf, 1955.

29. Jezus en de Kerken, p. 87.
} 
hulle almal verklaarbaar sou wees (vgl. Keller!). By Elisa se wonder van die drywende byl word dan verklaar dat Elisa 'n stok in die water gegooi het wat juis in die holte van die byl ingegaan en sodoende 'n nuwe steel gevorm en dan gevolglik die byl laat drywe het! Maar nou is die probleem met so ' $n$ verklaring van die wonder, dat dit die wonder uit die wonder haal ${ }^{30}$ ). Andersyds is dit ook so dat die Ou Testament vir ons dikwels die heerlike waarheid verkondig dat Gods hand juis in die daaglikse wetmatighede en vanselfsprekendhede aanwesig is, ja dat hierdie dinge juis almal wonders is! Andersyds is dit waar dat ons by Elia en Elisa eintlik in ' $n$ heel ander wêreld beland - daar is byna elke trek in wat vertel word 'n wonder. Daarom word daar gevra of hierdie profetevertellinge nie miskien tipiese volksverhale was nie, en of ons, as ons van 'n esel hoor wat spreek en van 'n mens wat deur 'n groot vis opgesluk is, nie met 'n sogenaamde midrasj te doen het nie - met ander woorde met 'n verhalende verklaring van die Skrifte $^{31}$ ).

Ten slotte moet nog verwys word na verskeie verskille van weergawes van feite wat daar in die Ou Testament aan te wys is. Kuitert noem ' $n$ hele ry voorbeelde van verskille tussen die boeke Samuel/Konings en 1 en 2 Kronieke $^{32}$ ).

Maar ook wat die Nuwe Testament betref, word daar deur geleerdes vandag talle voorbeelde genoem wat moet aantoon dat ook die boodskap van die Nuwe Testament met 'n sekere verpakking gepaard gaan - veral omdat vele gegewens nie as feitelike weergawes gelees kan word nie. Die standpunt van Brunner ten opsigte van die maagdelike geboorte het in die jongste tyd verrassende steun gevind, van manne waarvan dit nooit eintlik verwag is nie - van iemand soos Althaus, maar ook van die behoudende kerkhistorikus $\mathrm{H}$. F. von Campenhausen en Pannenberg. En die belangrikste feit in die verband is dat al drie hierdie geleerdes hulle argumente aan die Bybel self ontleen! Die Bybel self raak dit vir ons onmoontlik om aan die maagdelike geboorte as 'n feit te glo! Dit is die argumentasie van hierdie teoloë $\left.{ }^{33}\right)$.

In verband met die verhoor van Jesus word daar vandag in Duitsland die vraag gestel of daar wel 'n verhoor voor die Joodse Raad was, aangesien daar gegewens buite die Bybel om is wat daarop dui dat die Joodse Raad wél oor die sogenaamde halsreg beskik het. Lohse kom in hierdie verband tot die konklusie dat

3i. Vgl. Koole, a.w. 53.

31. Vgl. Bijlsma, a.w. p. 12, Kuitert, a.w. p. 41.

32. P. 9-.

33. Althaus, Die christliche Wahrheit, p. 23 en 217-. Pannenberg, Grundziige der Christologie, p. 142-. Vgl. Harenberg, a.w. p. 66-. 
die beskrywing van die verhoor van Jesus deur Markus „'n historiese verslag wil gee, maar ook die stempel dra van die belydenis en van die polemiese debatte wat die gemeente met die sinagoge moes voer"34).

Dan staan ons natuurlik voor die pertinente verskil in weergawes van verskillende feite deur die onderskeie skrywers van die Nuwe Testament. Mattheüs vertel vir ons dat die dissipels sonder skoene uitgestuur is (10:10), terwyl Markus net die teenoorgestelde skrywe (6:9). Die verskille in verband met die blinde(s) by Jerigo is welbekend: By Lukas genees Jesus 'n blinde man en daarná lees ons dat Jesus Jerigo binnegegaan het. Maar by Mattheüs en Markus geskied die genesing eers as Jesus Jerigo verlaat - en dan geld dit by Mattheüs van twéé blindes. So lees ons van die maaltyd en Betanië dat dit by Mattheüs en Markus ná die intog in Jerusalem plaasgevind het, maar by Johannes geskied dit voordat Jesus triomfantlik Jerusalem binnery en word dit in verband gebring met die opwekking van Lasarus. Volgens die weergawe van Mattheüs skeur die voorhangsel ná Jesus se sterwe, by Lukas s'n heelduidelik daarvóór ${ }^{35}$ ).

Dit is natuurlik oorbekend dat sekere dinge wat deur een of meer van hulle beskrywe word by die ander ontbreek. Maar nou is daar ook voorbeelde hiervan wat soms vir teoloë groot probleme bied. So plaas E. Hirsch 'n groot vraagteken oor die opwekking van Lasarus: „Die opwekking van 'n in ontbindingverkerende lyk uit 'n graf, sou as dit werklik gebeur het, die allergrootste daad van Jesus gewees het. Geen enkele Evangelie sou hierdie daad kon oorslaan nie" - en tog word dit net by die Johannes-evangelie aangetref ${ }^{36}$ ).

En dan so iets dat Mattheüs in 27:9 'n woord van die profeet Sagaria siteer, maar dit dan aan Jeremia toeskryf. Calvyn sê dat hy nie angstig wil soek of dit dalk êrens in Jeremia gevind kan word nie; die naam Jeremia het ongetwyfeld deur 'n vergissing ingesluip ${ }^{3 i}$ ).

En terwyl ons nou van aanhalings praat, moet daar opgemerk word dat die gebruikmaking van aanhalings uit die Ou Testament deur die Nuwe Testament, iets merkwaardigs is: dit is besonder opvallend dat die Nuwe Testament hom hier 'n groot mate van vryheid veroorloof. Heel dikwels word in plaas van die Hebreeuse teks dié van die Septuagint gebruik én die ander woord- of feiteorde van laasgenoemde nagevolg ${ }^{38}$ ). En nou word daar op grond

\footnotetext{
34. By Harenberg, a.w. p. 101-.

Tj. Baarda, De hetroubaarheid van de Evangelien (Cahier 2) noem in dié verband vele voorbeelde.

36. E. Hirsch by Harenberg, a.w. pp. 76-77.

.Certe Ierremiae nomen errore positum esse pro Zacharia . . ."

is. Vele voorbeelde by Bijlsma, bv. p. 40.
} 
daarvan gevra of dit nie as absolute bewys moet dien dat dit vir die Nuwe Testament nie in die eerste plek om historiese feite gaan nie, maar om die eintlike boodskap wat hy wil bring vandaar die vraag of die historiese omlysting nie dikwels alleen maar die inkleding van die boodskap is nie.

\section{KONKLUSIE:}

Sonder om op alle vrae te probeer antwoord - die gedagte van die lesing was meer om die probleem aan die orde te probeer stel - wil ons enkele stellinge hier maak wat nie uit die oog verloor mag word nie.

Stelling 1: Geloof is geen quantum van leerstellings nie. Die geloof is nie 'n leë sak waarvan die wese is dat dit moet dien as ' $n$ reservoir vir bepaalde geloofstukke nie - waarvolgens die reël dan ongeveer geld dat as dit die voorgeskrewe aantal christelike geloofstukke bevat, dit dan 'n christelike geloof sou wees nie ${ }^{3 \theta}$ ). Nee, die geloof is 'n daad. Geloof is 'n eksistensiële saak wat die mens in sy totaliteit raak. Daarom gaan dit nie in die geloof om sekere eksakte historiese waarhede nie, maar om God wat waaragtig is. Daarom maak dit nie saak of $\mathrm{Ai}$ met dertig of 5,000 man in 'n hinderlaag gelok is nie, of Sisera gelê of gestaan het toe Jael hom met 'n tentpen gedood het nie (die verskil tussen Rigters 4 en 5!), of met hoeveel mense Israel uit Egipte weggetrek het nie en hoe oud Metusalem was nie, of Elisa werklik die yster laat dryf het en of Jona alleen maar 'n midrasj is nie.

Maar dan moet ons ook die tweede stelling daarmee saamneem: dat dit ook nie beteken dat die eksistensiële beslissing van die geloof ' $n$ historiese ondergrond kan mis nie! Bultman het die eerste stelling wat ons hierbo genoem het sodanig op die keper gedryf dat hy dit „eine fatale Argumentation" noem as Paulus in 1 Kor. 15 die ooggetuies van die opstanding van Christus by die naam noem $\left.{ }^{40}\right)$. Op dieselfde wyse word die evangelis Lukas deur Günther Klein verwyt omdat hy in sy proloog die geloof histories sou wou bewys en grond ${ }^{* 1}$ ). Maar met hierdie „fatale manier van argumenteer" het Bultman hom die grootste kritiek onder andere ook van sy eie leerlinge op die hals gehaal! Dis daarom dat Bohren hom met reg kan verwyt dat van die groot drama van God by hom alleen 'n eksistensialistiese „Kammerspiel" oorgebly het. En sy leerling Käsemann dat die Kerygma wat die handele van God aan die wêreld betuig, by Bultmann tot 'n „Entscheidungruf" verkort is. En Knevels: Bultmann se

39. Vgl. Ebeling: Christelijk Geloof, p. 21.

40. Theologie des N.T., p. 300 .

41. Aangehaal by Berkouwer, I, p. 220. 
„Enthmythologisierung” kom eintlik neer op „Entkerygmatisering" ${ }^{22}$ ). Bultmann se grootste leerling Käsemann het op grond hiervan sodanig tot reaksie gekom dat hy 'n hele teëbeweging op tou gesit het: terug na die historiese Jesus!

Nee, die evangelie het 'n inhoud. Fides qua, maar ook en veral fides quae! Ons tref in die Bybel menslike getuies aan en hulle kom elkeen met subjektiewe interpretasies, maar wie daaruit gaan besluit dat hierdie getuienisse eerder 'n selfekspressie van die vertellende getuie as die verslag van 'n gebeurtenis is, het dit heeltemal mis! ${ }^{43}$ ). En dit is eienaardig dat Bultmann ook in 'n onderhoud wat Der Spiegel met hom gehad het, baie sterk daarop gestaan het dat ook hy glo dat Jesus Christus uit die dode opgestaan het! $\left.{ }^{14}\right)$.

Stelling 3: Om die Bybel werklik te laat sê wat hy self wil sê, moet ons baie deeglik rekening hou met die menslike by die totstandkoming van die Skrif. Ons het reeds daarop gewys dat Calvyn hierdie saak sodanig in berekening gebring het dat hy rustig van 'n vergissing by Mattheüs kon praat. As ons werklik die Skrif as sy eie „Interpres" wil eer, sal ons moet toegee dat die Bybel nooit die menslike faktor probeer wegsteek en oneffenhede probeer gladstryk nie. Die samesteller van Josua 8 toon dat hy twee oorleweringe ken: een wat spreek van 30,000 man en 'n ander van 5,000; en in plaas daarvan om op sy eie manier te probeer om dit te laat rym, laat hy dit liewer net so - dieselfde geld van Genesis 1 en 2, en ander gedeeltes. En as ons dit erken, word die wonder en die boodskap van die Skrif daardeur kleiner gemaak? Nee, beslis nie! Ook nie as dit uit Lukas 17:11 blyk dat Lukas nie die geografie van Palestina geken het nie; of dat Paulus in Galate 4 Sinaî 'n berg in Arabië noem nie.

Stelling 4: Nog baie belangriker is dit om rekening te hou met die doel waarmee die boeke van die Bybel geskryf is. Die Skrif is 'n tendensboek. Dit wil nie geskiedenis weergee nie, maar die Woord van God. Die woord evangelie beteken dan ook nie geskrif nie maar mondelinge boodskap. Die Boeke van die Bybel is almal opgeskrewe verkondiging, wat opnuut verkondig wil word. En in hierdie verkondiging gaan dit nie in die érste plek om historiese feitelikhede nie - hoewel ons reeds pertinent gesê het dat dit nie beteken dat die evangelie in die lug hang nie! - maar om die Messias, om Jesus Christus! Vandaar dat ons dit reeds by die vertaling van die Septuagint aangetref het:

\footnotetext{
12. O.a. Käsemann, Exeget. Versuche II, p. 31-, en Knevels, Die Wirklichkeit Gottes, p. 119.

13. Mooi by Kuitert, De Realiteit van het Geloof, p. 177-.

44. Sien Harenberg, a.w., p. 191-.
} 
dat dit nie maar net vertaling was nie, maar verkondigende vertaling ${ }^{45}$ ). Die woorde word na die Messias omgebuig. So word die „bed" van Genesis 47:31 tot 'n „staf" - die staf van die Messias. En ook hierdie geaktualiseerde vertolking dra die gesag van die spreke van God, omdat dit in die oorbring van die teks die Messias verkondig. En as Hebreërs 11:21 hierdie vers uit die Ou Testament aanhaal, gebruik dit die woorde van die Septuagint: want dit gaan om die Messias. „Julle ondersoek die Skrifte ... dit is dié wat van My getuig" (Joh. 5:39). Christus is die einde van die wet, die einddoel van die Ou Testament (Rom. 10:4). „En Filippus het „van hierdie Skrif af begin en die evangelie van Jesus aan hom verkondig" (Hand. 8:35). Ons het in die Bybel nie met 'n „notarieel verslag" (Kuyper) te doen nie, maar met 'n getuienis van mense wat met die saak waarvan hulle berig gee, op lewe en dood verbonde is. „Al was 'n boek oor aardrykskunde byvoorbeeld geheel en al ingegee en in die mees letterlike sin van woord tot woord gedikteer, word dit daardeur nog nie theopneust in die sin van 2 Tim. 3:16 nie. Die skrif is die Woord van God omdat die Heilige Gees daarin van Christus getuig, omdat dit die vleesgeworde Woord tot stof en inhoud het" (Bavinck). Die Bybel bied ons nie foto's wat met 'n kamera geneem is nie, maar skiderye. Die Bybel is een groot skildery.

Die Bybel bied ons ook geskiedenis. Natuurlik! Maar dit is altyd weer inklusiewe geskiedenis (Barth). Genesis 3 is nie in die eerste plek 'n venster nie - dit ook! Daar is 'n venster - maar dit is en bly altyd 'n spieël. Wie daarin kyk en homself nie sien nie, het nog nie werklik gekyk nie.

Dit is duidelik dat ons van 'n inkleding van die boodskap van die Skrif sal moet spreek. En dit is net so duidelik dat ons nie net daarvan kan práát nie, maar baie deeglik daarmee rekening moet hou. Ons sien maar al te goed waartoe 'n teologie lei wat dit nie in berekening bring nie, en alle tekste uit alle Bybelboeke eenvoudig gelykskakel soos die blokkies waarmee 'n kind sy toring bou - soos wat dit byvoorbeeld gebeur by die Jehowagetuies. Alleen langs die weg van 'n verantwoordelike eksegese - wat grondig vra na die literêre genre van die boek en gedeelte onder bespreking, na die historiese agtergrond daarvan en na die doel waarmee dit geskryf is - kan die boodskap daarvan ver. neem word.

45. Mooi by Bijlsma, p. 40. 
Daar is dus in die Skrif verskil tussen, soos Kuitert dit noem „getuienis en historiese klankbodem". Om dié onderskeiding nie te maak nie, lei tot biblisisme: dit stel getuienis én klankbodem absoluut en kom dan daartoe om, op straf van verlies van die saligheid, almal te dwing om byvoorbeeld te aanvaar dat die mens en die wêreld net 6,000 jaar oud is.

Maar nou mag ons nie weer die fout van die 19de eeu se teologie begaan, om getuienis en klankbodem, inkleding en boodskap te skei nie - en die inkleding dan as blote verpakking te beskou, wat soos by die ontvangs van 'n pakket summier weggegooi kan word nie. Nee, wie na julle luister, sê Jesus aan die apostels, luister na My. „Wie u hoort, die hoort Mij." Alleen deur en deur middel van húlle woorde en getuienis, kan Jesus gehoor word. Christus kom na ons in die gewaad van die Skrif en wie die Christus nie aanneem soos Hy met sy evangelie bekleed is nie, stry teen sy Woord (Calvyn). 